\title{
AN INTEGRATIVE REVIEW OF THE LITERATURE
}

\begin{abstract}
The risk of drug interaction (DI), especially in the hospital setting, increases along with the number of drugs used by the patient. Studies that evaluate drug interactions based on patient prescriptions are therefore useful to know this risk and guide strategies to improve drug use. The present study is aimed to identify studies that evaluated DI in patients of Brazilian hospitals. As of bibliographic search in several databases, we collected articles describing prescribing evaluations which focused on the analysis and identification of drug interactions in Brazilian hospitals. The search was conducted in 2017 and there was no restriction of publication time. Of a total of 273 articles retrieved, 23 were included for analysis. Most was published after 2010, and the predominant design was cross-sectional studies. The Micromedex database was the most used to categorize the interactions, and midazolam and fentanyl was the most commonly reported potential DI in the studies. The results may guide futures research which should assess the real harm of IMP in patients and, then, promote the rational use of drugs,
\end{abstract}

Key words: drug interactions, hospital, Brazil, prescription

\section{INTRODUCTION}

Prescriptions with increasingly complex combinations result in difficulties for healthcare professionals involved in the use of medications - prescribing, dispensing and administration - to recognize potential drug interactions. ${ }^{1,2}$ In 2006 Becker et al concluded that the use of two or more drugs increases the risk of potential drug interactions (PDI), leading to hospitalization due to worsening illness or even death. ${ }^{3}$

Therefore, the risk of drug interaction increases proportionally with the number of drugs prescribed to the patient and, if the patient is hospitalized, risks increase due to polypharmacy. ${ }^{4,5}$ In this sense, in hospital clinical units, this topic deserves special focus, since polypharmacy, added to the severity and instability of the patients' clinical status, is an extremely relevant factor for their vulnerability. ${ }^{6}$

The estimates of the occurrence of PDI are between $3 \%$ and $5 \%$, in patients who use two to nine drugs, and 20\% among those who use 10 to 20 drugs, simultaneously. ${ }^{4}$ Older data shows distinct results but corroborates with the premise that the risk of interaction increases with the number of drugs used. Goldberg et al (1996) state that PDIs occur in 13\% of patients taking two drugs and in $85 \%$ of patients taking more than six drugs.

Hammes et al. cite data from the Harvard Medical Practice Study which revealed that complications related to drug use represent the most common type of adverse events in hospital admission (19\% of patients), and $2 \%$ to $3 \%$ of hospitalized patients experience reactions specifically caused by PDI. ${ }^{8}$

In a study published in the year 2000, Meneses and Monteiro performed a study in intensive care units (ICU) in which the potential of drug interactions could occur from $44.3 \%$ to $95.0 \%$ of patients. $^{9}$

In 2014, Gimenes et al. analyzed 289 prescriptions for patients in Intensive Care Units (ICUs), in a Brazilian hospital, in which $65.4 \%$ of the prescriptions exposed the patient to the risk of PDI, being classified, especially, as severe (50.2\%) and moderate $(42.3 \%)$. In this same study it was verified that the most common MP was that between midazolam and fentanyl, and, on the other hand, the drug most related to MP was amiodarone. ${ }^{10}$

In view of the high risk that hospitalized patients have of developing PDI, it is important to know the profile of the prescriptions that make PDI possible in Brazilian hospitals. To this end, drug prescription studies (EUM) can be used to build information that enables interventions to promote the rational use of medicines. ${ }^{11}$ In this sense, literature review shows a strategy to identify this profile.

Thus, the objective of this study was to know the profile of the studies developed with the purpose of identifying the PDIs in patients hospitalized in Brazilian hospitals.

\section{METHODOLOGY}

An integrative review of studies on the use of drugs developed in hospitals in Brazil was carried out. The databases for searching the scientific articles were PubMed, Scientific Electronic Library On Line (Scielo) and Virtual Health Library (VHL).

The search for original articles considered the following descriptors and Boolean connectors: a) Scielo: Drug interactions and hospital, Brazil and study and prescription; drug interactions and hospital
1. Universidade de Brasília Faculdade de Ceilândia, Centro Metropolitano Grupo de Pesquisa: Acesso a Medicamentos e Uso Responsável - AMUR

Submitted: $17 / 03 / 18$

Resubmitted: 04/12/18 Aceptted: 18/12/18

How to cite this paper: Yamagata AT, Júnior RMCB, Galato D, Meiners MMMA, Silva

EV. Profile of studies of potential drug interactions in brazilian hospitals: an integrative review of the literature. Rev

Bras Farm Hosp Serv Saude, 9(4): 1-9, 2018.

Doi: $10.30968 /$ rbfhss.2018.094.003

Autor correspondente: emiliavitoria67@gmail.com 
and Brazil and study and prescription. b) PubMed: drug interactions and hospital and Brazil; drug interaction and hospital and observational study; drug interactions and hospital and Pharmacoepidemiology c) VHL: Drug interaction and hospital and Brazil. Search strategies were executed distinctly due to the particularities of each database. Research was not limited only to articles, and academic documents could be inserted, if they were available in the databases consulted. There was no search in gray literature.

The bibliographic survey was carried out in December 2017, including works published until this month. There was no restriction regarding the year of publication of the papers. The following inclusion criteria were considered: 1) studies carried out in Brazil; 2) observational studies; 3) articles describing a survey of prescriptions for the purpose of identifying and characterizing drug interactions; 4) studies performed in hospitals; 5) articles available in full.

Initially, duplicate articles were excluded. In the second stage, titles and abstracts were read and analyzed, and the all of the work done in other non-hospital health units, those carried out in other countries, articles of revision, or that had a non-observational design was excluded. All of the work that went through this scrutiny was reviewed in its entirety, excluding those who did not approach surveying drug interactions, even if they were kept in the previous stage.

The process of selecting papers for the present article was performed through peer review, independently. The divergences were discussed between the two authors until a consensus was reached on the articles that would, in fact, be selected and analyzed.

The following information was extracted from the studies included: authorship, year of publication, type of study, time of research (duration of data collection), sample (number of patients and prescriptions), age group, prevalence of PDI, source of information used to describe them, categorization of interactions according to the source consulted, more frequent PDI, whether the study was general or specific for a particular group of drugs, source for data collection and place of work execution.

For the purpose of categorizing PDI, those considered to be "serious" are those that are contraindicated or that represent a risk of death or require medical intervention in the patient. The sources of information commonly used to verify drug interactions bring this categorization. However, when the data of the original works was extracted, the classification used by the authors of each manuscript was respected.

It is also important to clarify that the studies analyzed in this review describe potential drug interactions, that is, that their potential was identified against the analysis of the prescriptions, but that because there was no follow-up of the patients, there was no confirmation of its occurrence.

Since this is a review of the literature, this study was not submitted to a Research Ethics Committee (REC).

\section{RESULTS AND DISCUSSION}

In the search 273 articles were found, after the different stages, 23 papers were selected for this review, according to the flowchart shown in Figure 1.

In view of the selected studies, it was observed that all of them describe studies that were performed in hospitals of medium or high complexity.

Table 1 summarizes the data for the articles included in this review.

Figure 1. Flowchart of search of articles in databases on drug interactions in Brazilian hospitals

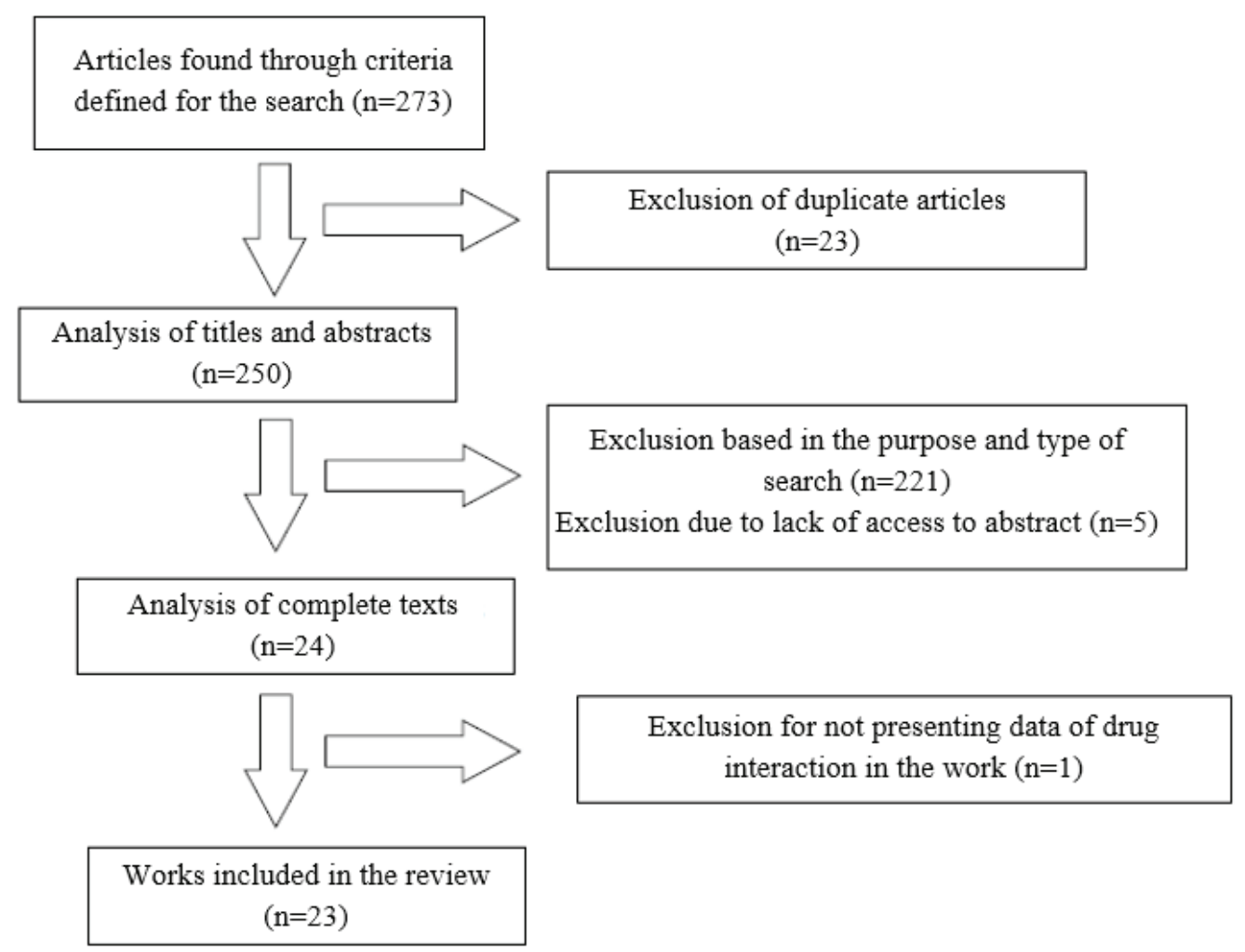

Source: the authors themselves, 2018. 
Table 1: General characteristics of the articles included in this integrative review on drug interactions in Brazilian hospitals.

\begin{tabular}{|c|c|c|c|c|c|c|c|}
\hline \multicolumn{2}{|l|}{ Author } & $\begin{array}{l}\text { Miyasaka e Atallah } \\
(2003)\end{array}$ & $\begin{array}{l}\text { Riechelmann } \\
(2005)\end{array}$ & $\begin{array}{l}\text { Cruciol-Souza } \\
(2006)\end{array}$ & Junior (2008) & Furini (2009) & Lima (2009) \\
\hline \multicolumn{2}{|c|}{ Type of study } & $\begin{array}{l}\text { Retrospective, } \\
\text { quantitative }\end{array}$ & $\begin{array}{l}\text { Retrospective, } \\
\text { quantitative }\end{array}$ & $\begin{array}{l}\text { Retrospective, case- } \\
\text { control }\end{array}$ & $\begin{array}{l}\text { Descriptive, cross- } \\
\text { sectional }\end{array}$ & Retrospective & $\begin{array}{l}\text { Descriptive, } \\
\text { exploratory and cross- } \\
\text { sectional }\end{array}$ \\
\hline \multicolumn{2}{|c|}{ Study time } & 49 months & 6 months & 4 months & 11 months & 32 days & 12 months \\
\hline \multicolumn{2}{|c|}{$\begin{array}{l}\text { Sample (number of } \\
\text { patients) }\end{array}$} & 7242 & 100 & 1,785 & 47 & 100 & 102 \\
\hline \multicolumn{2}{|c|}{$\begin{array}{l}\text { Sample (number of } \\
\text { prescriptions) }\end{array}$} & Not informed & Not informed & Not informed & Not informed & 100 & Not informed \\
\hline \multicolumn{2}{|c|}{ Age group } & Not informed & 20 to 94 years old & 12 to 98 years old & Not informed & Over 15 years old & 18 to 96 years old \\
\hline \multicolumn{2}{|c|}{ Source used } & Micromedex ${ }^{\circ}$ & $\begin{array}{l}\text { Drug Interaction } \\
\text { Facts software }\end{array}$ & Micromedex $^{\circ}$ & Not informed & $\begin{array}{l}\text { Drug Interaction } \\
\text { Facts on Disc and } \\
\text { Vade-Mécum }\end{array}$ & Micromedex \\
\hline \multicolumn{2}{|c|}{ Prevalence of PDI } & $\begin{array}{l}\text { Of } 169 \text { patients } \\
\text { who received } \\
\text { antidepressants, MI } \\
\text { was observed in } 36 \\
(20.3 \%) \text {. }\end{array}$ & $\begin{array}{l}63 \% \text { of patients with } \\
\text { PDI. }\end{array}$ & $\begin{array}{l}49.7 \% \text { of the } \\
\text { prescriptions }\end{array}$ & Not informed. & Not informed & $\begin{array}{l}74 \text { of the } 102 \text { patients } \\
\text { analyzed }(72.5 \%) .\end{array}$ \\
\hline \multicolumn{2}{|c|}{ Most frequent PDI } & Not informed. & $\begin{array}{l}\text { Opioids + } \\
\text { BZD(I),ISRS(II) } \\
\text { +AINES(III) with } \\
\text { HBPM(IV) }\end{array}$ & $\begin{array}{l}\text { Digoxin + } \\
\text { Hydrochlorothiazide } \\
(3.4 \%)\end{array}$ & $\begin{array}{l}\text { Dipyrone + Captopril } \\
(76.6 \%)\end{array}$ & $\begin{array}{l}\text { Cephalexin and } \\
\text { Ketoprofen }\end{array}$ & $\begin{array}{l}\text { Midazolam }+ \\
\text { Fentanyl }(14.5 \%)\end{array}$ \\
\hline \multirow{3}{*}{$\mathrm{PDI}^{*} \%$} & Mild & Not informed. & $25.00 \%(\mathrm{~V})$ & Not informed & Not informed & $21.40 \%$ & Not informed \\
\hline & Moderate & Not informed. & $56.70 \%(\mathrm{~V})$ & Not informed & Not informed & $56.30 \%$ & Not informed \\
\hline & Severe & Not informed. & $18.30 \%(V)$ & Not informed & Not informed & $21.40 \%$ & Not informed \\
\hline \multicolumn{2}{|c|}{$\begin{array}{l}\text { Scope of clinical or general } \\
\text { / specific patients }\end{array}$} & Specific & Specific & General & Specific & Specific & General \\
\hline \multicolumn{2}{|c|}{$\begin{array}{l}\text { Instrument for information } \\
\text { gathering }\end{array}$} & Medical record & Medical record & Medical record & $\begin{array}{l}\text { Medical record and } \\
\text { direct interview with } \\
\text { the patient }\end{array}$ & Medical record & Medical record \\
\hline \multicolumn{2}{|c|}{ Location } & Sao Paulo & Sao Paulo & Londrina - Paraná & Paraíba & Mirassol - São Paulo & Ceará \\
\hline
\end{tabular}

*PDI according to authors' classification

To be continued. 


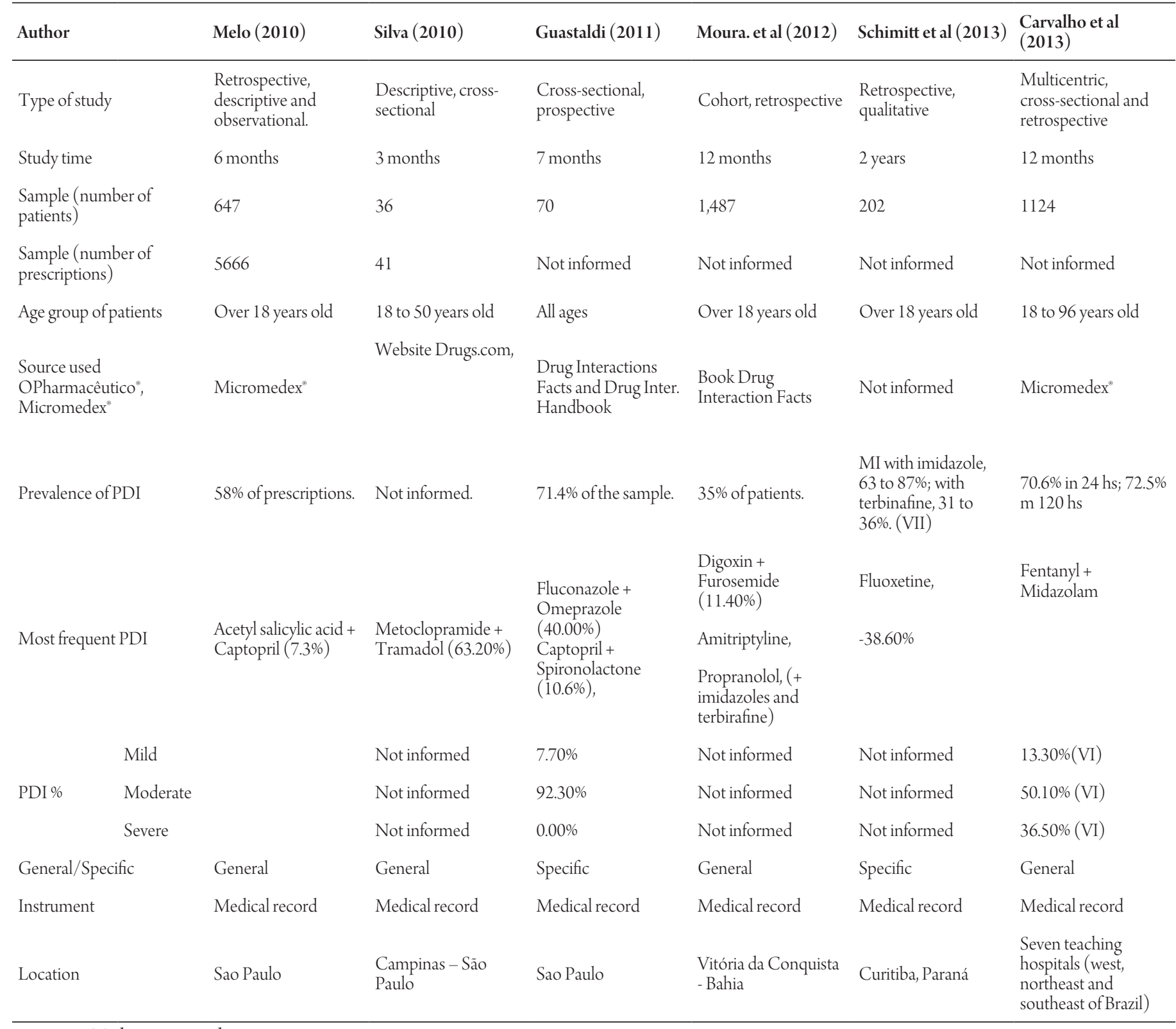

To be continued. 
To be continued.

\begin{tabular}{|c|c|c|c|c|c|c|}
\hline \multicolumn{2}{|l|}{ Author } & Okuno et al (2013) & Cedraz e Junior (2014) & Reinert et al (2015) & Antunes et al (2015) & Furini (2015) \\
\hline \multicolumn{2}{|c|}{ Type of study } & $\begin{array}{l}\text { Cross-sectional and } \\
\text { descriptive }\end{array}$ & $\begin{array}{l}\text { Quantitative, descriptive } \\
\text { and cross-sectional }\end{array}$ & Cross-sectional & Cross-sectional & Retrospective \\
\hline \multicolumn{2}{|c|}{ Study time } & 5 months & 4 months & 3 weeks & 4 months & 12 months \\
\hline \multicolumn{2}{|c|}{$\begin{array}{l}\text { Sample (number of } \\
\text { patients) }\end{array}$} & 200 & Not informed & 56 patients & Not informed & 40 patients \\
\hline \multicolumn{2}{|c|}{$\begin{array}{l}\text { Sample (number of } \\
\text { prescriptions) }\end{array}$} & Not informed & 28 & Not informed & 101 & Not informed \\
\hline \multicolumn{2}{|c|}{ Age group of patients } & Over 18 years old & $\begin{array}{l}\text { Not informed (Average } \\
\text { age: } 48.54 \text { ) }\end{array}$ & 27 to 78 years old & $>60$ years old & Not informed \\
\hline \multicolumn{2}{|c|}{$\begin{array}{l}\text { Source used } \\
\text { OPharmacêutico } \\
\text { Micromedex }^{\circ}\end{array}$} & Website Drugs.com & Micromedex & $\begin{array}{l}\text { UpToDate and } \\
\text { Medscape }^{\circ}\end{array}$ & Website Drugs.com & $\begin{array}{l}\text { Website Drugs. } \\
\text { com, Micromedex e } \\
\text { Medscape }\end{array}$ \\
\hline \multicolumn{2}{|c|}{ Prevalence of PDI } & $79.5 \%$ of the prescriptions. & $\begin{array}{l}92.86 \% \text { of the } \\
\text { prescriptions. }\end{array}$ & $19.5 \%$ of patients. & $\begin{array}{l}\text { Informed separately, } \\
\text { according to severity. }\end{array}$ & Not informed. \\
\hline \multicolumn{2}{|c|}{ Most frequent PDI } & $\begin{array}{l}\text { Metoclopramide + } \\
\text { Tramadol }(30.40 \%) \\
(11.11 \%) ; \\
\text { Dipyrone + Enoxaparin } \\
(11.11 \%)\end{array}$ & Fentanyl + Midazolam & $\begin{array}{l}\text { Antidepressants and } \\
\text { antineoplastics }\end{array}$ & $\begin{array}{l}\text { Enalapril + } \\
\text { Spironolactone }(6.4 \%)\end{array}$ & Ritonavir + Tenofovir \\
\hline \multirow{3}{*}{ PDI \% } & Mild & $12.00 \%$ & $5.05 \%$ & Not informed & $7 \%$ & Not informed \\
\hline & Moderate & $67.00 \%$ & $58.59 \%$ & Not informed & $26.80 \%$ & Not informed \\
\hline & Severe & $21.00 \%$ & $31.31 \%$ & $8.9 \%$ & $7 \%$ & $8 \%$ \\
\hline \multicolumn{2}{|c|}{ General/Specific } & General & General & General & Specific & Specific \\
\hline \multicolumn{2}{|c|}{ Instrument } & Medical record & Medical record & $\begin{array}{l}\text { Medical record and direct } \\
\text { interview with the patient }\end{array}$ & Medical record & $\begin{array}{l}\text { Medical record and } \\
\text { direct interview }\end{array}$ \\
\hline \multicolumn{2}{|l|}{ Location } & Sao Paulo & Feira de Santana - Bahia & $\begin{array}{l}\text { Porto Alegre - Rio Grande } \\
\text { do Sul }\end{array}$ & São Paulo - São Paulo & $\begin{array}{l}\text { São josé do Rio Preto - } \\
\text { São Paulo }\end{array}$ \\
\hline
\end{tabular}




\begin{tabular}{|c|c|c|c|c|c|c|}
\hline \multicolumn{2}{|l|}{ Author } & Oliveira Et al (2015) & Alvim et al (2015) & Guidoni et al (2016) & Moreira et al (2017) & Ferracini et al (2017) \\
\hline \multicolumn{2}{|c|}{ Type of study } & $\begin{array}{l}\text { Descriptive and } \\
\text { Retrospective }\end{array}$ & Cross-sectional & Cross-sectional & Retrospective & Cross-sectional \\
\hline \multicolumn{2}{|c|}{ Study time } & 12 months & 3 months & 72 months & 12 months & 11 months \\
\hline \multicolumn{2}{|c|}{$\begin{array}{l}\text { Sample (number of } \\
\text { patients) }\end{array}$} & Not informed & 82 patients & 3048 patients & 485 patients & 58 patients \\
\hline \multicolumn{2}{|c|}{$\begin{array}{l}\text { Sample (number of } \\
\text { prescriptions) }\end{array}$} & 725 & 656 & 42120 & 319 & 305 \\
\hline \multicolumn{2}{|c|}{ Age group } & Not informed & 18 to 89 years old & Not informed & Not informed & 19 to 46 years old \\
\hline \multicolumn{2}{|c|}{ Source used } & $\begin{array}{l}\text { Website Drugs.come } \\
\text { Micromedex }\end{array}$ & Micromedex & Lexi-Interact $^{\circ}$ & Micromedex & Micromedex \\
\hline \multicolumn{2}{|c|}{ Prevalence of PDI } & $\begin{array}{l}21 \% \text { according to } \\
\text { Micromedex; } 36 \% \text { as } \\
\text { per Drugs.com }\end{array}$ & $\begin{array}{l}98 \mathrm{MI} \text { in } 46 \% \text { of } \\
\text { patients evaluated. }\end{array}$ & $\begin{array}{l}48.7 \% \text { of prescriptions } \\
\text { with MI. }\end{array}$ & Not informed. & $91 \%$ of prescriptions. \\
\hline \multicolumn{2}{|c|}{ Most frequent PDI } & $\begin{array}{l}\text { Haloperidol + } \\
\text { Promethazine }(17.7 \%)\end{array}$ & $\begin{array}{l}\text { Fluconazole + } \\
\text { Omeprazole }\end{array}$ & Warfarin + Enoxaparin & Midazolam + Fentanyl & $\begin{array}{l}\text { Dipyrone + enoxaparin } \\
\text { sodium }\end{array}$ \\
\hline \multirow{3}{*}{ PDI \% } & Mild & Not informed & $2 \%$ & Not informed & Not informed & $71.60 \%$ \\
\hline & Moderate & $1 \%$ & $16 \%$ & Not informed & Not informed & $22.20 \%$ \\
\hline & Severe & $20 \%$ & $50 \%$ & Not informed & Not informed & $4.90 \%$ \\
\hline \multicolumn{2}{|c|}{ General/Specific } & Specific & Specific & Specific & Specific & Specific \\
\hline \multicolumn{2}{|c|}{ Instrument } & Medical record & Prescriptions & Prescriptions & Prescriptions & Prescriptions \\
\hline \multicolumn{2}{|c|}{ Location } & $\begin{array}{l}\text { Uberlândia - Minas } \\
\text { Gerais }\end{array}$ & $\begin{array}{l}\text { Juiz de Fora - Minas } \\
\text { Gerais }\end{array}$ & $\begin{array}{l}\text { Ribeirão Preto - São } \\
\text { Paulo }\end{array}$ & $\begin{array}{l}\text { Rio de Janeiro - Rio de } \\
\text { Janeiro }\end{array}$ & Campinas - São Paulo \\
\hline
\end{tabular}
(I) BZD (benzodiazepines)
(II) SSRIs (selective serotonin reuptake inhibitor)
(III) NSAIDs (non-steroidal anti-inflammatory drugs)
(IV) LMWH (low molecular weight heparin)
(V) PDI (potential drug interaction) of 63 patients detected as PDI
(VI) 24-hour data after hospitalization
(VII) Dependent on the amount of medication used by the patient

Analyzing the results of this integrative review, and considering that there was no restriction of the search period in the databases, it was observed that the retrieved articles are between the period of 2003 and 2017, with a predominance of those published from 2010 to here, that is, are relatively recent work. This indicates a positive aspect, which points to a greater interest in studying the prescriptions in hospitals and measuring their quality regarding drug interactions. These initiatives may be useful for detecting recurrent pharmacotherapy-related problems and targeting strategies to improve the prescribing pattern and thus the patient's health.

In 2007, Carvalho et al published a bibliographical review analyzing and identifying studies of drug use in Brazilian hospitals, in which it observed that the number of studies aimed at the use of drugs in hospitals has grown gradually since the $1980 \mathrm{~s}^{34}$ This same tendency of increase was observed in the present research.

Regarding the study design of the articles described in Table 1, it can be observed that the studies are categorized by the authors more commonly as retrospective (cohorts) or cross-sectional studies. Although convenient and low-cost forms adopted in prescription analysis studies, once requiring only trained professionals and access to the patient's medical records (or any other document containing the medications used), they have important limitations. The main one is with regard to the possibility of nonreliability of the information collected or even loss of data. ${ }^{35}$ In any case, they are useful for obtaining a picture of the use of medicines from a health service. In addition, this fact drives in that the interactions identified are always described as potential since, even if they occurred, there is no data recorded about it.

One of the most relevant aspects of a research is to delimit observation time. In this review, the work of Furini et al (2009), ${ }^{16}$ who collected data for 32 days, and the work of Miyasaka and Atallah (2003), ${ }^{12}$ whose collection occurred during 4 years and 1 month, showing a large variation in the temporal aspect. What can be argued regarding the time factor in prescription studies is that very short ones can be of low precision and long 
ones can generate repetitive results. ${ }^{36}$ However, the analysis of the studies included in this review does not allow us to presume an adequate time for the evaluation of PDI. Several factors may interfere with the accuracy of the results of a drug use study, and the sample is one of the most important. Calculation of the sample, in turn, depends on the research question, the type of study and also the population to be investigated, in this case often translated as the number of hospital beds in which the study is being conducted in addition to the frequency of the event that you want to measure, ${ }^{35}$ having a relation with the error that will be tolerated. Therefore, in prescribing studies, sample calculation is minimally advisable and, in this case, search time will be derived from this sample.

Regarding the patient's age, this review did not intend to stratify this aspect; however, seven of the 23 included studies did not report the age of patients, $12,15,25,28,29,31,32$ one stated that it included all ages ${ }^{20}$ and two exclusively covered prescriptions for pediatric patients. ${ }^{14,16}$

Analyzing Table 1, it can be seen that the sample size of each study varied greatly, in which there is no standard of study time in relation to the number of patients studied, i.e., the longer the observation time the greater the number of prescriptions included.

It was observed that, in general, Micromedex ${ }^{\circ}$ was the most used query source, on account of the current low cost due to availability, because it is accessible to many researchers, reliable and contains a lot of information. This database is available on the Capes Portal, accessible to Brazilian universities, ${ }^{37}$ and the Evidence Based Health Portal, available to all health professionals enrolled in their respective professional councils. ${ }^{38}$ It should be noted that this availability has provided greater base access in recent years.

However, the study by Mountford et al (2010) ${ }^{39}$ showed the use of other research platforms, such as Lexi-comp On line and Clinical Pharmacology that have superior quality and performance to Micromedex. This can be seen in another study, developed in Brazil, in which the authors found discrepancies between four information sources describing drug interactions, including Micromedex ${ }^{*} 40$

Considering, therefore, the potential heterogeneity between the sources used in the studies described in this review, it is not possible to make a full comparative analysis between them. In addition, despite the method used in each analysis of potential drug interactions, it is recommended that at least two sources of information be used when this type of study is desired.

As a source of data collection, the patient's medical record was the basis for the research of all the works. The use of medical records is very convenient because they are generally easily accessible, they contain relevant information such as patient evolution and it is possible to relate the use of medications as well as adverse events related to medications and other health care. It is a tool widely used in retrospective studies; but when poorly filled or if it omits information, it ends up weakening the study, especially when these are retrospective, as previously discussed. The interview with the patient is essential, since it increases the veracity of the information contained in the medical record and provides more reliable information.

An overview of this review shows that most of the selected articles are concentrated in the Southeast region of the country, but studies have been carried out in all regions of the country, maintaining a trend already observed by Magarinos-Torres et al. (2007). ${ }^{41}$.

Regarding the characterization of drug interactions in the studies that evaluated the intensity of PDI, it can be observed that the PDIs with moderate/severe classification are generally the most frequent. Interaction between midazolam and fentanyl was repeated in four studies, with captopril and spironolactone being cited in two studies and metoclopramide and tramadol in two articles, all considered severe or moderate, according to Micromedex" (2018).37

Considering the severity of these interactions and their high prevalence in prescriptions evaluated in different studies, it is possible to propose pharmacotherapeutic follow-up work specifically aimed at monitoring adverse events in patients using these drugs. According to Zheng et al. (2018), the prevalence of PDI does not predict the occurrence of drug interactions that will cause harm to the patient. The authors concluded this after a meta-analysis with a systematic review that found that 33\% of hospitalized patients and $67 \%$ of those admitted to intensive care experience a potential drug interaction. ${ }^{42}$

Notwithstanding its relevance, this paper's main limitation is not to be a systematic review, which would result in a better level of evidence. ${ }^{43}$ The scope of the survey was also compromised by involving only Brazilian hospitals and excluding those articles that were not available in full. In addition, the fact that only the most frequent PDI cited in each study has been highlighted may compromise the scenario of possible interactions in patients admitted to hospitals in Brazil. In addition, not including the gray literature also restricts the scope of this research.

In any case, it serves as a picture of the panorama of the way PDIs are being investigated in Brazil. Considering the most recent Global Patient Safety Challenge of the World Health Organization, ${ }^{44}$ which aims to reduce the damages caused by medication errors, knowledge of the PDI profile can be guiding strategies for the development of actions to promote the safe and rational use of medications.

\section{Final considerations}

In this integrative review it was possible to observe the profile of prescription studies that evaluate drug interaction in Brazilian hospitals, adopting the research in medical records without contact with the patient or follow-up of the same. In addition, they use, in particular, Internet databases such as Micromedex. In addition, they investigate a reduced number of patients/prescriptions which is generally related to the observation period. In this sense, the most used study drawings are retrospective (cohort) and cross-sectional; being performed predominantly in hospitals of medium/ high complexity.

Regarding the PDIs profile, it was observed that they were not classified in all studies, but in those that were the most frequent was moderate, one of the most frequent being that involving midazolam and fentanyl.

Future studies are needed; however, they should seek the outcomes of the PDIs on the patient, involving those clinical, humanistic and economic. In addition, safe prescribing should be a strategy for all those involved in patient care, so the development of prevention strategies should be a priority in hospitals.

\section{Funding sources}

This work was the result of the ProIC/DPP/UnB - PIBIC (CNPq) 2014/2015 Proi/DPP/UnB Scientific Initiation Program of the University of Brasilia, in which then student Adriana Tiemi Yamagata was a scholarship holder.

\section{Contributors}

ATY and RMPCBJ carried out a review of the literature, systematization of information and writing of the manuscript. DG and MMMAM collaborated with the discussion of the results and performed a critical review of the manuscript. EVS was responsible for designing the project, guiding it in its execution, reviewing and writing the final manuscript.

\section{Acknowledgment}

To the University of Brasilia, through its scientific initiation program; the team of research group Access to Medicines and Responsible Use AMUR and Pamela Alejandra Saavredra and Hellen Karoline Maniero for the indispensable collaborations.

\section{Conflict of interest}

The authors have no conflict of interest with any company or entity related to the subject of the review. 


\section{REFERENCES}

1. Trato DS. Drug interactions facts. St Louis: Facts and Comparisons: 2005.

2. Secoli SR, Figueiras A, Lebrão ML et al. Risk of potential drug-drug interactions among Brazilian elderly: a population-based, crosssectional study. Drugs Aging, 2007, 27(9):759-70.

3. Becker ML, Kallewaard M, Caspers PW, et al. Hospitalisations and emergency department visits due to drug-drug interactions: a literature review. Pharmacoepidemiol Drug Saf. 2006,16(6):641-51.

4. Ferreira-Sobrinho F. Avaliação de interações medicamentosas em prescrições de pacientes hospitalizados. Rev Racine, 2006,16(94):67-70

5. Rocha PCF, Mota PS e Oliveira CIFB. Prevalência de potenciais interações medicamentosas em uma unidade de terapia intensiva de Manaus- AM. Rev. Bras. Farm, 2014, 95 (3): 909 - 923.

6. Melo ABR, Silva LD. Segurança na terapia medicamentosa: uma revisão bibliográfica. Escola Anna Nery, 2008,12:166-72.

7. Goldberg RM, Mabee J, Chan L et al. Drug-drug and drug-disease interactions in the ED: analysis of a high-risk population. Am J Emerg Med, 1996,14(5):447-50.

8. Hammes JA, Pfuetzenreiter F, Silveira F et al. Prevalência de potenciais interações medicamentosas droga-droga em unidades de terapia intensiva. Rev Bras Ter Intensiva, 2008, 20(4):354-9.

9. Meneses, A., Monteiro, H.S. Prevalência de interações medicamentosas "droga-droga” potenciais em duas UTIs (pública X privada) de Fortaleza, Brasil. Rev Bras Ter Intensiva 2000;12(1):4-7.

10. Gimeses AHS, Baroni MMF, Nascimento PJ et al. Interações medicamentosas potenciais em unidade de terapia intensiva adulto de um hospital público estadual. Revista SBRAFH, 2014, 5(4): 19-24.

11. Castro CGSO (coord). Estudos de utilização de medicamentos: noções básicas [online]. Rio de Janeiro, Editora FIOCRUZ, 2000: 92.

12. Miyasaka LS, Atallah AN. Risk of drug interaction: combination of antidepressants and other drugs. Rev. Saúde Pública [online], 2003, 37(2):212-215.

13. Riechelmann RP, Moreira F, Smaletz $\mathrm{O}$ et al. Potential for drug interactions in hospitalized cancer patients. Cancer Chemother Pharmacol, 2005, 56: 286-290.

14. Cruciol-Sousa JM, Thomson, J.C. A pharmacoepidemiologic study of drug interactions in a Brazilian teaching hospital. Clinics [online], 2006, 61(6): 515-520.

15. Silva-Junior ED, Sette IMF, Belém LF et al. Interação medicamentosa entre anti-inflamatórios não-esteróides e anti-hipertensivos em pacientes hipertensos internados em um hospital público: uma abordagem em farmacovigilância. Rev. Baiana Saúde Pública, 2008, 32(1): 18-28.

16. .Furini AAC, Gomes AM, Silva CO et al. Estudo de indicadores de prescrição, interações medicamentosas e classificação de risco ao feto em prescrições de gestantes da cidade de Mirassol - São Paulo. Rev Ciênc Farm Básica Apl, 2009, 30(2):211-216.

17. Lima REF, Cassiani SHB. Potential drug interactions in intensive care patients at a teaching hospital. Rev. Latino-Am. Enfermagem [online], 2009, 17(2): 222-27.
18. Melo, D.O. Avaliação de interações medicamentosas potenciais para pacientes internados na clínica médica do Hospital Universitário da USP visando à elaboração de instrumento para identificação de eventos adversos a medicamentos evitáveis. Tese de Doutorado. Universidade de São Paulo, São Paulo, 2010.

19. Silva NMO, Carvalho RP, Bernardes ACA et al. Avaliação de potenciais interações medicamentosas em prescrições de pacientes internadas, em hospital público universitário especializado em saúde da mulher, em Campinas-SP. Rev Ciênc Farm Básica Apl, 2010, 31(2):171-76.

20. Gustaldi RBF, Secoli SR. Interações medicamentosas de antimicrobianos utilizados em transplante de células-tronco hematopoéticas. Rev Latino-Am Enferm, 2011, 19 (4): 1-8.

21. .Moura CS, Tavares LS, Acurcio FA. Interação medicamentosa associada à reinternação hospitalar: estudo retrospectivo em um hospital geral. Rev Saúde Pública [online], 2012, 46 (6): 1082-89.

22. Schimitt JV, Bombonatto G, Fabri AB. General aspects of drug interactions with systemic antifungals in a retrospective study sample. An Bras Dermatol, 2013, 88(3):476-9.

23. Carvalho REFL, Reis AMM, Faria LMP et al. Prevalência de interações medicamentosas em unidades de terapia intensiva no Brasil. Acta Paul Enferm [online], 2013, 26 (2): 150-57.

24. Okuno MFP, Cintra RS, Vancini-Campanharo CR et al. Interação medicamentosa no serviço de emergência. Einstein (São Paulo) [online], 2013, 11(4): 462-66.

25. Cedraz KN, Junior MCS. Identificação e caracterização de interações medicamentosas em prescrições médicas da unidade de terapia intensiva de um hospital público da cidade de Feira de Santana, BA. Rev Soc Bras Clin Med. 2014, 12(2): 1-7.

26. Reinert CA, Ribas MR, Zimmermann PR. Drug interactions between antineoplastic and antidepressant agents: analysis of patients seen at an oncology clinic at a general hospital. Trends in Psychiatry and Psychotherapy. 2015,37(2):87-93.

27. Antunes JFS, Okuno MFP, Lopes MCBT et al. Interação medicamentosa em idosos internados no serviço de emergência de um hospital universitário. Rev Min Enferm, 2015, 19(4):907-18

28. Furini AAC, Lima TAM, Rodrigues JF et al. Análise de interações medicamentosas e alimentares em pacientes com AIDS em uso da TARV associada à terapia de resgate. Rev Ciênc Farm Básica Apl., 2015, 36(3):427-434.

29. Oliveira LP, Zago KSdA, Aguiar SB. Potenciais interações medicamentosas em um serviço de urgência psiquiátrica de um hospital geral: análise das primeiras vinte e quatro horas. Rev eletrônica saúde mental alcool drog, 2015, 11(4):190-8.

30. Alvim MM, Silva LA, Leite ICG, Silvério MS. Eventos adversos por interações medicamentosas potenciais em unidade de terapia intensiva de um hospital de ensino. Revista Brasileira de Terapia Intensiva. 2015,27(4):353-9.

31. Guidoni CM, Camargo HP, Obreli-Neto PR et al. Study of warfarin utilization in hospitalized patients: analysis of possible drug interactions. Int J Clin Pharm. 2016,38(5):1048-51.

32. Moreira MB, Mesquita MGdR, Stipp MAC, Paes GO. Potential 
intravenous drug interactions in intensive care. Rev Esc Enferm USP. 2017,51: 1-8.

33. Ferracini AC, Rodrigues AT, Visacri MB et al. Potential Drug Interactions and Drug Risk during Pregnancy and Breastfeeding: An Observational Study in a Women's Health Intensive Care Unit. Rev Bras Ginecol Obstet. 2017,39(6):258-64.

34. Carvalho JM, Magarinos-Torres R, Osório-de-Castro CGS. Estudos de utilização de medicamentos em hospitais brasileiros: uma revisão bibliográfica. Rev Bras Farm, 2007, 88(2): 77-82.

35. Laporte JR, Tognoni G. Estudios de utilización de medicamentos y farmacovigilância. In: Laporte JR, Tognoni G (org.). Principios de epidemiologia del medicamento. 2. Ed. Ediciones Científicas y Técnicas: Barcelona, 1993: 259p

36. Luiz, R.R. Magnanini, M.M.F. A lógica da determinação do tamanho da amostra em investigações epidemiológicas. Cad. Saúde Coletiva, 2000, 8 (2): 9-28, 2000.

37. Portal de Periódicos Capes. Coordenação de Aperfeiçoamento de Pessoal de Nível Superior. Sitio da Internet. Disponível em: http:// www.periodicos.capes.gov.br/. Acessado em: 20 jan 2018.

38. Portal Saúde Baseada em Evidências. Ministério da Saúde. Organização Panamericana da Saúde. Sítio da Internet. Disponível em: http://psbe.ufrn.br/. Acessado em 20 jan 2018.

39. Mountford CM, Lee T, Lemos J et al. Quality and Usability of Common Drug Information Databases. CJHP, 2010, 63 (2): 130-7.

40. Martins MAP, Ribeiro, DD, Nobre VA, Pereira FR, Ribeiro ALP. Agreement among four drug information sources for the occurrence of warfarin drug interactions in Brazilian heart disease patients with a high prevalence of Trypanosoma cruzi infection. Eur J Clin Pharmacol. 2013, 69:919-28.

41. Magarinos-Torres R, Osório-de-Castro CGS, Pepe VLE. Pharmaceutical services for inpatients provided by hospital pharmacies in Brazil: a review of the literature. Cien Saude Colet. 2007;12(4):973-84

42. Zheng et al. Drug-drug interactions and their harmful effects in hospitalised patients: a systematic review and meta-analysis. Eur J Clin Pharmacol. 2018; 74(1):15-27.

43. Pereira MG, Galvão TF, Silva MT. Saúde Baseada em Evidências. Rio de Janeiro: Guanabara-Koogan. 2016.

44. World Health Organization. Medication Without Harm - Global Patient Safety Challenge on Medication Safety. Geneva: World Health Organization, 2017 